\title{
Entrepreneurship and Saudi Engineering Students: Intentions and Competencies
}

\author{
Hemaid Alsulami \\ Industrial Engineering Department, Faculty of Engineering, King Abdulaziz University ‘ Jeddah
21589, Saudi Arabia \\ healsulami@kau.edu.sa
}

\begin{abstract}
In recent years, entrepreneurship has opened many doors and opportunities for individuals and societies alike. In the case of Saudi Arabia, it could reduce the reliance on oil and contribute to the economy diversification. This research paper aims to investigating students' entrepreneurial intentions such as their level of interest, the time preference of starting their venture and preferences regarding a partnership. Further, it assesses the students' attainment level of skills that are deemed necessary for an entrepreneur to be successful. The research is also evaluating whether a university has any role in providing the students with the necessary skills and in which ways it does that. A survey was used to find answers to the research questions and was distributed to students in different regions of Saudi Arabia. The study found that about $80 \%$ of engineering students are interested in having an entrepreneurial career and the primary motivator behind this decision is to make more money than what is provide by a traditional job. Additionally, the majority of students prefer working for a few years before venturing on their own. The results show that skills and competencies such as decision making, effective communication, strategic and analytical thinking, flexibility and leadership were acquired at a better level than skills and competencies such as business acumen, risk taking, financial expertise and time management. Moreover, only $47 \%$ of participants believe that higher education schools have a role in equipping the students with the required skills, and the majority of those believe the university has helped them in attaining skills, such as project management skills through business administration courses.
\end{abstract}

Keywords: Entrepreneurship, Engineering Students, Intentions, Competencies, Saudi Arabia.

\section{Introduction}

Entrepreneurship involves designing, developing, launching and organizing new ventures. Entrepreneurship is characterized by innovation and risk-taking and is an essential part of a society ability to succeed in an ever changing and highly competitive global marketplace. Entrepreneurs are people with ambition who have a vision and determination to achieve their goals. They are equipped with a broad skillset and use innovative approaches to tackling the challenges that face their businesses. In the engineering campus of Stanford, there is a strong interest in the field of technology entrepreneurship, and they have a large student body interested in creating practical things that have a positive impact in the world. The fact that Silicon Valley leads excited people to work in the tech industry and support them with required skills to work in their companies in the future is what makes Stanford University stands out in the 
entrepreneurship fields among other universities. Numerous booming businesses around the globe were started by young entrepreneurs and those businesses played a crucial role in job creation and are considered to be a key factor in developing the economy. Startup companies make up $25 \%$ in the Kingdom $^{[1]}$, while in 2014, there was a growth in jobs for both Saudi and Non-Saudi. The unemployment rate for nationals remains considerably high and stands at $11.7 \%^{[2]}$. Entrepreneurship could be the answer to decreasing the issue of unemployment especially for females since their unemployment rate is higher than their male counterparts. Further, entrepreneurship can lead to economic growth that is diversified and not heavily reliant on oil. Therefore, the youth should be motivated to become entrepreneurs, and they should acquire the skills to be successful in their endeavor. The aim of this research is to measure the interest level of engineering students and determine what motivate them to pursue entrepreneurship. Furthermore, it aims at evaluating their readiness to start their ventures and create job opportunities for themselves and others by measuring their entrepreneurial skills since there are claims that Saudi graduates do not have the necessary skills to enter the labor force nor start a business venture ${ }^{[3]}$. Also, the research proposes ways to equip the students with the vital skills they lack to close the skills gap to be prepared to become the next generation of potential entrepreneurs.

There is a lack of interest in pursuing an entrepreneurial career that seeks to solve the issue of unemployment and the economic growth in Saudi Arabia. There is also insufficient emphasis given to the importance of training and rehabilitation of students to be qualified and as such create companies and new jobs in Saudi Arabia.
This paper is intends to find answers for the following questions:

1. What are the entrepreneurial intentions among engineering students and the key motivators behind the decision?

2. What is the percentage of students who are equipped with the sufficient entrepreneurial skills and competencies?

3. What is the role of the university in providing the students with the necessary skills?

\section{Literature Review}

The two terms of entrepreneurs and small business owner are used interchangeably but Cuervo et al. ${ }^{[4]}$ indicate that there is a distinction between them and they claim that risk bearing is one of the distinguishing factors as the former tend to be more inclined to take risks while the latter does not. There is also another indication that innovation in addition to the employment of strategic management to grow the business are considered to be the main characteristic that distinguish between the two terms.

\section{Entrepreneurial Competencies}

According to Mitchelmore \& Rowley ${ }^{[5]}$, competencies of entrepreneurship are essential to have a growing and a successful business. The core competencies that entrepreneurs possess empower them to succeed and have a fruitful business. Kaur and Bains ${ }^{[6]}$ stated that these competencies take many forms such as follows:

- Strategy Competency: The ability to develop a clear vision, plan effectively for the future and set short and long-term goals.

- Commitment Competency: Having the drive and dedication to growing a fruitful business. 
- Conceptual Competency: Possessing analytical skills and decision-making ability to analyse complexities that may arise and reason the decision by weighing the opportunities and risks.

- Opportunity Competency: The ability to recognize and take advantage of the prospective opportunities in addition to understanding the changing needs to be competitive.

- Relationship Competency: The ability to communicate clearly and become entrepreneurs to convey the underlying message. This competency also includes the ability to persuade and influence others.

- Ethical Competency: Being aware of ethics and ethical dilemmas.

- Learning competency: The ability to employ the skills that allow one to adapt to the dynamic nature of the entrepreneur roles.

- Technical competency: The ability to utilize the tools and techniques that aresuitable to the business needs.

- Personal Competency: The personal characteristics that enhance the effectiveness of the individual in managing challenging tasks. This competency also allows them to identify strengths and match them with opportunities and utilize them in overcoming threats. Moreover, it enables them to identify weaknesses that might hinders the utilization of possible opportunities or worsen the threats.

Sorensen and Chang ${ }^{[7]}$ stated that some characteristics and factors which contribute to the business success and these include factors related to psychology such as the aspiration for achievement and personal qualities and also factors related to education and experience which suggests that there is a correlation between the level of education and the performance.
Nemours studies have investigated the motivation and interest of students in entrepreneurship. Wang and Wong ${ }^{[8]}$ stated that entrepreneurship education and knowledge are the main factors that shape the potential to possess an entrepreneurial attitude. They also state that there are some factors that affect the entrepreneurial propensity, such as gender as males mostly aspire more than females to become entrepreneurs. It was also noted that family business background influences the interest of their children in entrepreneurship. They assert the individuals with self-employed parents are more likely to follow in their footsteps. Baycan and Nijkamp ${ }^{[9]}$ assessed the level of interest in entrepreneurship and its key factors among students in which it was mentioned that many studies suggest that the background is a factor influencing entrepreneurial motivation. This study has found that there is a difference in motivation between genders as female students look for more job alternatives and seek a higher position whereas males showed greater interest in becoming entrepreneurs as well as the high status in society. The study had also found that students from different backgrounds are more interested in becoming self-employed than natives, so this suggests that ethnicity could have an effect on the overall interest. Samuel et al. ${ }^{[10]}$ had investigated the key motivators for students to become entrepreneurs which included utilizing talent, creating job opportunities, earning a living, pursuing their dreams and having job security. This study had also found that there are some obstacles that discourage students from wanting to become entrepreneurs such as lack of savings, lack of experience in business and the difficulty of finding the partners. Moreover, Ahmad et al. ${ }^{[11]}$ found that the majority of students associate innovation, risk taking and capital with the term entrepreneur and stated that the majority of student believes that entrepreneurs are made rather than born. 
The study found that upon graduation, the majority of students prefer working in a company before creating their own business, while some prefer working full time while running their own simultaneously.

Innovation is required to solve problems and to maintain competitiveness of Saudi Arabia globally, and engineering is the foundation of innovation. Engineers are prepared to enter the workforce and they thrive in the changes in global economy. Engineers can collaborate effectively as leaders. In addition to their systematic thinking, technical and analytical background, they have the ability to realize and seize opportunities under any economic and social conditions ${ }^{[9]}$. All of these innovative and entrepreneurial skills should be educated as part of engineering education and it is the responsibility of engineering colleges and educators to gain these qualities in students.

In this research, the role of engineering education in habilitating the students for entrepreneurship was investigated, by analysis the efficiency of student skills and engineering faculty programs in entrepreneurship field. Then we offer our perspective on the future landscape for innovation and entrepreneurship in engineering education.

Engineers need to be qualified to understand and contribute to the market and business field. The engineers who have entrepreneurial skills and start their business after graduation have high level of experience in product design and development, prototyping, technology trends, and market analysis $^{[12]}$. These skills support them to success in their business and engineers, who join companies are better prepared to become competent managers and team members. Entrepreneurship education teaches engineering students in all disciplines the knowledge, tools, and attitudes that are required to identify opportunities. Students who take part in entrepreneurship programs as undergraduates gain perspicacity not available from traditional engineering education, such as working in and managing interdisciplinary teams, communicating effectively, understanding business basics, thinking critically and solving open-ended problems ${ }^{[13]}$.

\subsection{Methodology}

The study uses survey as a method to collect the required data. A pilot study was conducted on sample of engineering colleges students in King Abdulaziz university to test the clearance of the survey questions. A group of 20 students were requested to fill the questionnaire and based on their submission and feedback the survey was revised. In addition, the survey was sent to three experts to validate it in order to improve it. Then, the survey was distributed in an online form to engineering students in different regions of Saudi Arabia such as western, middle, and eastern regions. To reach out students in different universities Emails and messages feature in social media applications (such as WhatsApp, Twitter, Instagram, Facebook) were sent to representatives of these universities and they were asked to circulate it between students in engineering colleges. After filling the survey, students just click submission button and survey will be submitted and saved in an online data base. It takes three months to collect the required data from different regions. The survey identified the intentions of students regarding entrepreneurship such as their interest level in becoming entrepreneurs and the key motivators behind that decision. Further, it investigated the entrepreneurial competencies and skills that the students possess.

\subsection{Findings and Discussion}

After data collection was completed, the Microsoft Excel was used to analyze the data. 
More than 3000 responses were collected 40 $\%$ from western region, 30 middle region and 30 percent from the eastern region. From this sample $90 \%$ were male students while $10 \%$ female students which is reasonable, since most of engineering colleges in Saudi Arabia teaching only male students except few universities such as King Abdulaziz University. Around 120 responses were excluded based on the validation processes. The Likert Scale was used to evaluate participates level of agreement. A scale of $1-$ 5 used as 1 means least applicable and 5 means most applicable. The following sections represent the responses of each item in the survey.

\section{Entrepreneurial Intentions}

\subsection{Interest Level}

To answer the research question regarding entrepreneurial intention, the results show that $80 \%$ of the engineering students have interest in pursuing entrepreneurial career. From the sample, only $2 \%$ of participants show that they are not very interested to be entrepreneurs, $31 \%$ are somewhat interested, $37 \%$ are interested and $30 \%$ are very interested. The result indicates that students have shown some level of interest that is variable since some students have strong interest, as shown in Fig. 1. This results the high percentage of Saudi students in engineering colleges to become entrepreneurs comparing to previous studies that showed Saudi were interested in looking for a job instead of starting their own businesses.

\subsection{Working Preferences}

Figure 2 shows that $25 \%$ of the interested students in entrepreneurship prefer starting their own business individually, while $75 \%$ prefer working with partners. This preference could be because that many courses in engineering schools have projects that are team based and students feel that their performance is better when working with a group. This result is an indicator of the possibility that the proportion of partnership business and private companies in the future will increase in Saudi Arabia.

\subsection{Time of Pursuing Entrepreneur Career}

Figure 3 shows that of those who are interested in becoming entrepreneurs, $10 \%$ want to start their own business directly after graduation, $20 \%$ while studying, 20\% prefer working after graduation and start their own business as a part time simultaneously while $50 \%$ of the students prefer working after graduation for a period then start their own business. This finding implies that students want to get job experience before venturing on their on to learn some skills and increase their entrepreneurial success rates. The results show that most of students in the big cities such as Riyadh and Jeddah prefer to get experience in big companies to help them start their business in a better way. The other reason because the availability of job opportunities in these cities.

\section{Entrepreneurship Motivators}

Figure 4 shows that of those who are interested in becoming entrepreneurs, 54\% reported their interest because they want to be their own boss, $64 \%$ to make more money, $43 \%$ to create job opportunities in the community, $46 \%$ to utilize their talent, $12 \%$ to follow in their parent's footsteps, $37 \%$ to give back to the community while $62 \%$ reported their interest because they want to see their idea come to reality. In this question, the participants were allowed to choose their reason why did they are interested in entrepreneurship in order to find out the most three factors that affect their interest. The results show that following reasons are most three reasons why Saudi students in Engineering colleges keen to establish their own businesses: 
1. To make more money.

2. To see my idea for new products, service or improve products selling in the market.

3. To be my own boss.

\section{Obstacles of Pursuing Entrepreneurship}

The obstacles reported by students that might hinder them from pursuing entrepreneurship are lack mentorship as reported by $33 \%$, lacking financial support as reported and lacking knowledge and skills and finding business partners as reported by $51 \%$ and $18 \%$ of the respondents respectively as seen in Fig. 5. This finding was expected, since the main factor that hinders some people from pursuing entrepreneurship is due to finances. The results show also those students who replie of lacking of knowledge and skills are students who answered they are not interested in pursuing entrepreneurship, and students who were interested but they are juniors in the engineering college. Students who shows they are lack of mentorship most likely answered they are very interested or interested in entrepreneurship but they need mentors to help them to set up their business.

\section{Interest level of students in entrepreneurship}

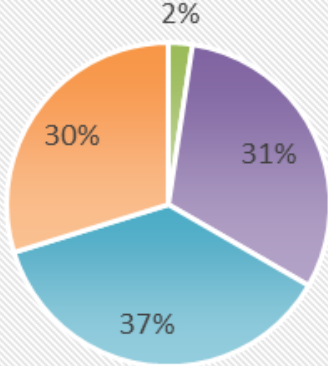

- 1 (Not Intrested at all)

$=2$

$-3$

$-4$

5 (very intrested)

Fig. 1. Interest level of students in entrepreneurship.

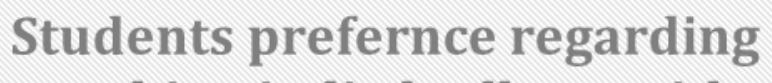

working indivdually or with

partners

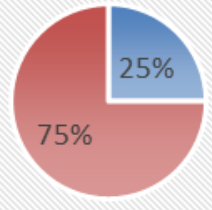

- individually

- With another partner or more

Fig. 2. Working preferences. 


\section{Students prefernce regarding the time to start the business}

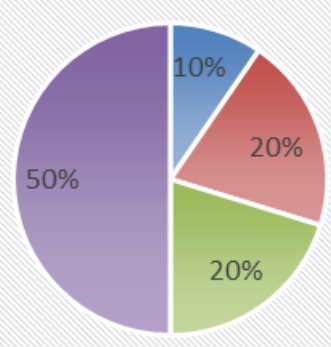

- Directly after graduation.

- While Studying.

- Working full time after graduation and start my business part time.

- Working full time after graduation for a few years and then start my own business.

Fig. 3. Time of starting the business.

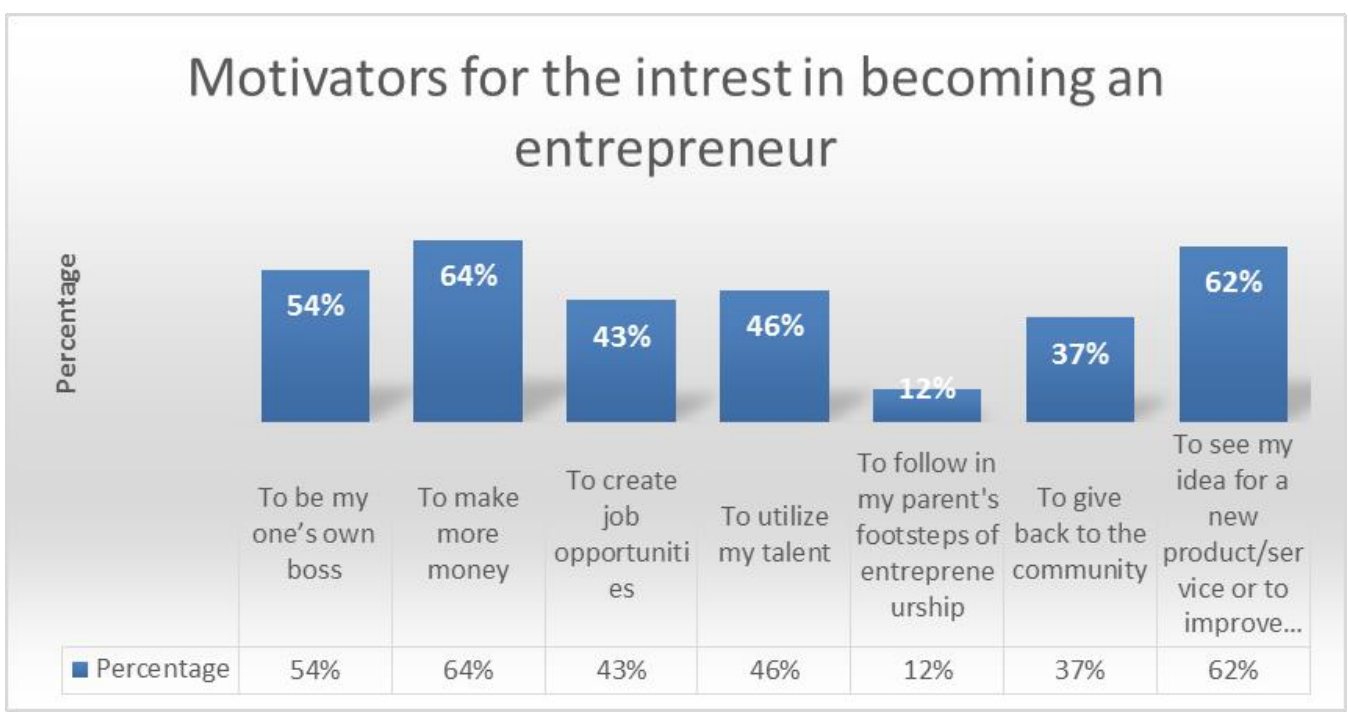

Fig. 4. Motivators for the interest in becoming an entrepreneur.

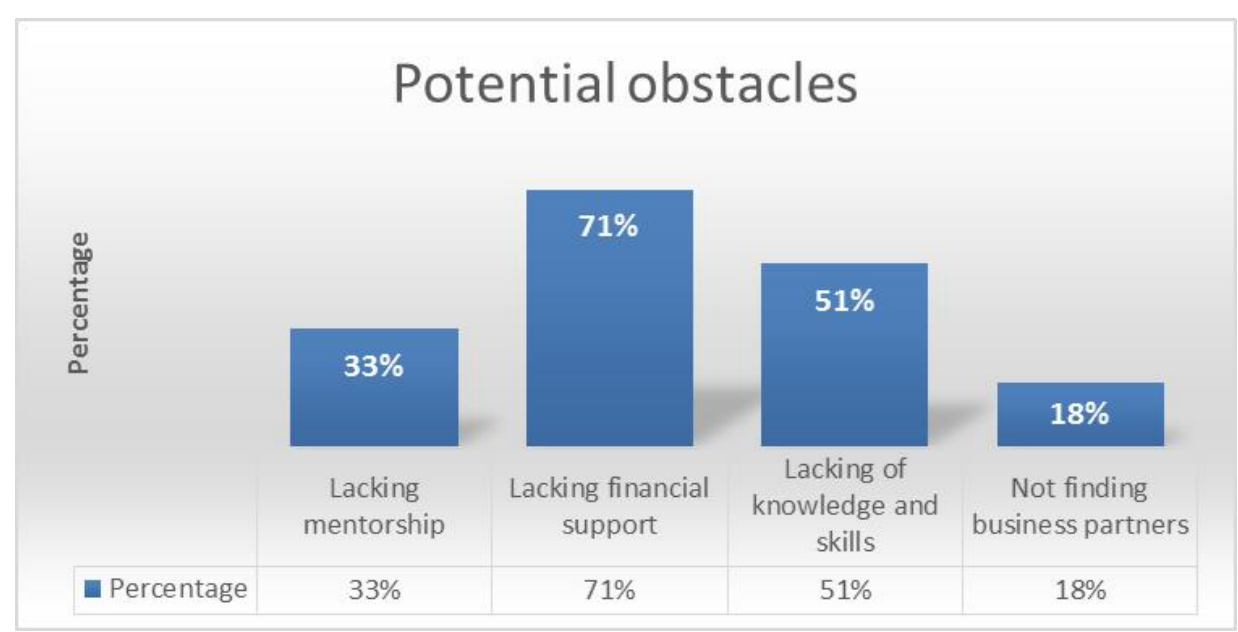

Fig. 5. Potential obstacles. 


\section{Entrepreneurial Skills}

In Table 1, students were asked to evaluate their attainment of the skills by selecting a number from 1 -which implies that the skills are not attained by the students at allto 5 -which implies that the skills are attained by the students at a good level.

Of the skills that are identified to be necessary for a successful entrepreneurial career, the table shows that most of students have rated themselves lower than 4 approximately $54 \%$ as shown in

Table 1, which is almost consistent of the percentage of students who selected lacking of knowledge and skills. Business acumen is the least possessed skill with $4 \%$ of the student having an advanced level, while leadership skills are the highest acquired at an advance level with $23 \%$ of the students. This finding could be due to the fact the students do not have business related hands-on experience since many have their first experience with real life business during their internships which is during the last few semesters of college.

The percentage of students possessing skills at an intermediate level or higher is greater for students interested in pursuing an entrepreneurial career than their counterparts as shown in Table 2. Thus, it can be concluded that students with good level of skills are more likely to pursue entrepreneurship particularly business acumen and risk taking because all other skills are required for any other type of work life

\section{University Education Role}

To answer the research question regarding the role of universities in equipping the students with the necessary skills, it was found that about $43 \%$ of the engineering students agree that universities have a role in equipping their students with the necessary skills, since many offers electives in management subject as shown in Fig. 6 . Therefore, it can be concluded that universities have impact on the qualification of entrepreneurs as well as the interest of engineering students.

Of those who think universities have a role in equipping their students with the necessary skills, $24 \%$ think the skills are acquired from extracurricular activities, while the majority thinks the skills are acquired through business management courses as shown in Fig. 7. This is because many students acquire skills from formal ways rather than informal ways such as extracurricular activities.

From the survey, it was found that $51 \%$, $78 \%, 36 \%, 56 \%$ and $56 \%$ of them think universities helped them in acquiring financial, project management, market research, designing and marketing skills, respectively as shown in Fig. 8. The percentage of student with project management skills is the highest, which could be due to the fact the many engineering schools offer courses covering these skills. On the other hand, the percentage of students who think universities taught them market research skill is the lowest. This finding was not expected since engineers have to understand the requirements of the customer to meet their expectation.

\section{Conclusion}

In conclusion, this study explores intentions of engineering students regarding entrepreneurship. The study shows that a staggering number of students intends on becoming entrepreneurs at some point in their life whether during university, after graduation directly or after some time or balancing between a job and an entrepreneurial project simultaneously. The study found that about $80 \%$ of engineering students are interested in having an entrepreneurial career and the 
primary motivator behind this decision is to make extra income than what is earned by a traditional job. The majority of students prefer working for a few years before venturing on their own. The results show that skills and competencies, such as decision making, effective communication, strategic and analytical thinking, flexibility and leadership were acquired at a better level than skills and competencies such as business acumen, risk taking, financial expertise and time management. Moreover, only $47 \%$ of participants think that higher education schools have a role in equipping the students with the required skills, and the majority of those believe the university has helped them in attaining skills, such as project management skills through business administration courses. Therefore, it is recommended that universities introduce entrepreneurship course to enhance student skills to start their businesses as $51 \%$ of students selected lacking of knowledge and skills as one of the obstacles that are facing when they are willing to start their businesses. It is also recommended that university provides new degree programs in entrepreneurship for those who intent to purse their bachelor or master degrees in this field.
Moreover, the university may offer training courses in entrepreneurship which includes accounting for non-accountants, marketing for non-marketers, project management, feasibility studies and any related courses. Based on the results, it is recommended to establish business accelerators within university to encourage students build their business ideas. In addition, the university may establish business incubators to host won ideas from the accelerators for at least two years until it becomes mature venture. Accordingly, university with private sector partnership can reserve seed funds for those projects and work with local government agencies to facilitate their paper works. Also, University may collaborate with chamber of commerce to motivate private sectors to buy from those entrepreneurs.

To further enhance the outcomes of this study, it is recommended that student from other non-engineering disciplines be included in a future study. Further study the impact of the Saudi culture and government regulations on entrepreneurship as a factor affecting the interest and motivation of university students in Saudi Arabia is required.

Table 1. Students agreement level on skills acquired at good level.

\begin{tabular}{|l|c|c|c|c|c|}
\hline \multicolumn{1}{|c|}{ Skills } & $\begin{array}{c}1 \text { (Least } \\
\text { acquired) }\end{array}$ & $\begin{array}{c}2 \text { (Least } \\
\text { acquired) }\end{array}$ & $\begin{array}{c}3 \\
\text { (Neutral) }\end{array}$ & $\begin{array}{c}4 \text { (mostly } \\
\text { acquired) }\end{array}$ & $\begin{array}{c}5 \text { (Fully } \\
\text { acquired) }\end{array}$ \\
\hline Decision making & $14 \%$ & $11 \%$ & $22 \%$ & $36 \%$ & $16 \%$ \\
\hline Effective Communication & $13 \%$ & $14 \%$ & $23 \%$ & $29 \%$ & $21 \%$ \\
\hline Business Acumen & $16 \%$ & $22 \%$ & $29 \%$ & $30 \%$ & $4 \%$ \\
\hline Risk Taking & $20 \%$ & $20 \%$ & $24 \%$ & $25 \%$ & $11 \%$ \\
\hline Strategic and Analytical & $12 \%$ & $11 \%$ & $26 \%$ & $34 \%$ & $16 \%$ \\
\hline Thinking & $14 \%$ & $9 \%$ & $28 \%$ & $30 \%$ & $20 \%$ \\
\hline Adaptedness and Flexibility & $19 \%$ & $21 \%$ & $21 \%$ & $27 \%$ & $12 \%$ \\
\hline Financial Skills & $14 \%$ & $17 \%$ & $25 \%$ & $26 \%$ & $18 \%$ \\
\hline Time Management & $15 \%$ & $11 \%$ & $16 \%$ & $34 \%$ & $23 \%$ \\
\hline Leadership & & & & & \\
\hline
\end{tabular}


Table 2. Students agreement level on skills acquired at an intermediate level or higher

\begin{tabular}{|l|l|l|l|l|l|}
\hline \multicolumn{1}{|c|}{ Skills } & \multicolumn{1}{c|}{$\begin{array}{c}\text { 1(Least } \\
\text { acquired) }\end{array}$} & $\begin{array}{c}2 \text { (Least } \\
\text { acquired) }\end{array}$ & $\begin{array}{c}4 \\
\text { (Neutral) }\end{array}$ & $\begin{array}{c}\text { (mostly } \\
\text { acquired) }\end{array}$ & $\begin{array}{c}5 \text { (Fully } \\
\text { acquired) }\end{array}$ \\
\hline Decision making & $12 \%$ & $11 \%$ & $19 \%$ & $38 \%$ & $20 \%$ \\
\hline Effective Communication & $10 \%$ & $15 \%$ & $24 \%$ & $29 \%$ & $23 \%$ \\
\hline Business Acumen & $8 \%$ & $24 \%$ & $31 \%$ & $32 \%$ & $5 \%$ \\
\hline Risk Taking & $18 \%$ & $17 \%$ & $24 \%$ & $29 \%$ & $13 \%$ \\
\hline Strategic and Analytical Thinking & $10 \%$ & $11 \%$ & $29 \%$ & $35 \%$ & $17 \%$ \\
\hline Adaptedness and Flexibility & $10 \%$ & $11 \%$ & $24 \%$ & $35 \%$ & $21 \%$ \\
\hline Financial Skills & $14 \%$ & $19 \%$ & $23 \%$ & $31 \%$ & $13 \%$ \\
\hline Time Management & $10 \%$ & $20 \%$ & $23 \%$ & $29 \%$ & $19 \%$ \\
\hline Leadership & $12 \%$ & $13 \%$ & $12 \%$ & $36 \%$ & $27 \%$ \\
\hline
\end{tabular}

\section{University education role in equipping students with the necessary skills}

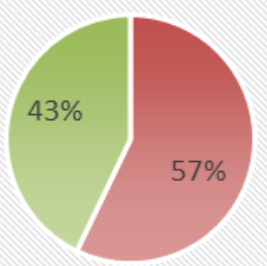

- Disagree

- Agree

Fig. 6. University education role.

\section{How universities equip the students with the necassary skills}

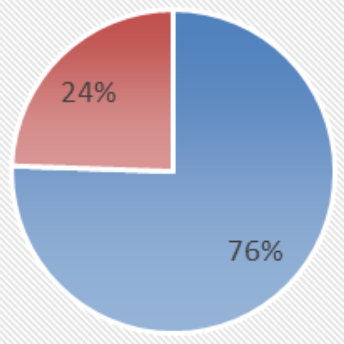

- Business Management

Courses

- Extracurricular Activities

Fig. 7. Ways of universities to equip students with the skills. 


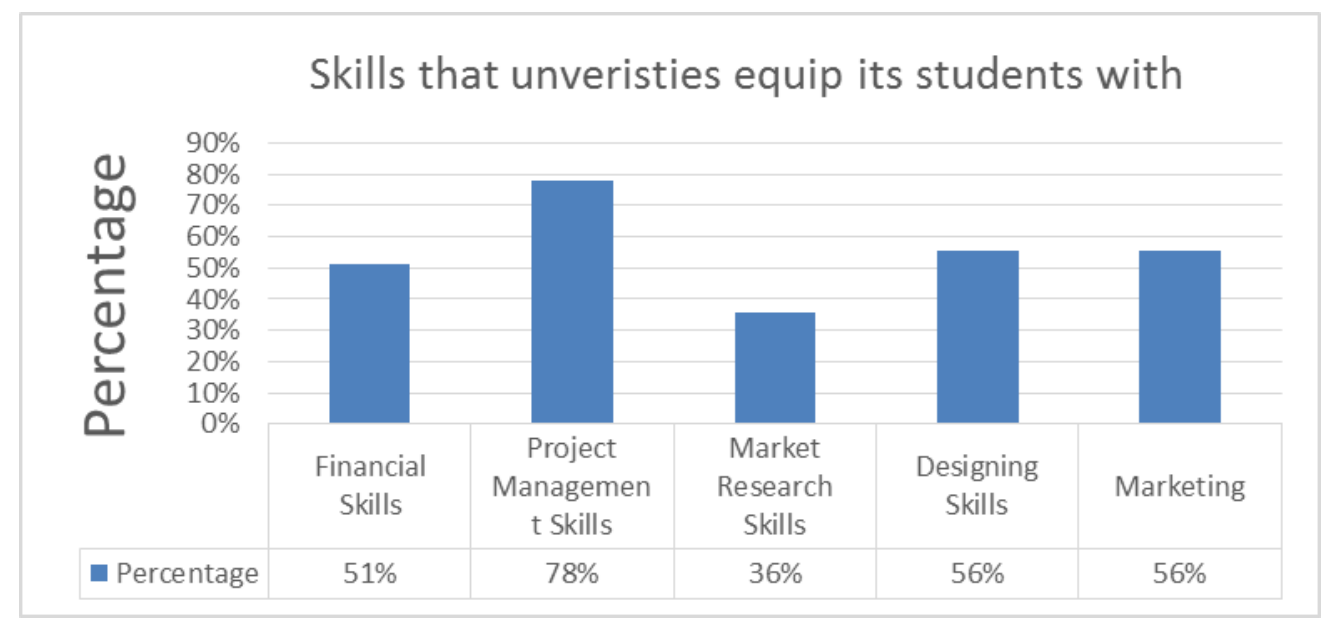

Fig. 8. Skills that universities equip its students with.

\section{References}

[1] EY G20 Saudi-Arabia Report (2013). Retrieved from http://www.ey.com/Publication/vwLUAssets/EY-G20country-report-2013-Saudi-Arabia/\$FILE/EY-G20country-report-2013-Saudi-Arabia.pdf

[2] International Monetary Fund Saudi Arabia Report (2015, September). Retrieved from: https://www.imf.org/ external/pubs/ft/scr/2015/cr15251.pdf

[3] How will the GCC close the skills gap? (2015). Retrieved from http://www.ey.com/Publication/vwLUAssets/EYgcc-education-report-how-will-the-gcc-close-the-skillsgap/\$FILE/GCC\%20Education\%20report\%20FINAL \%20 AU3093.pdf

[4] Cuervo, Á., Ribeiro, D. and Roig, S. (Eds.). Entrepreneurship: Concepts, Theory and Perspective. Springer Science \& Business Media (2007).

[5] Mitchelmore, S. and Rowley, J., Entrepreneurial competencies: a literature review and development agenda. International Journal of Entrepreneurial Behavior \& Research, 16(2): 92-111(2010).

[6] Kaur, H. and Bains, A., Understanding the concept of Entrepreneur Competency.J. Bus. Manag. Soc. Sci. Res., 2: 31-33 (2013).

[7] Sorensen, J. and Chang, P., Determinants of successful entrepreneurship: A review of the recent literature. Available at SSRN 1244663 (2006).
[8] Wang, C. K. and Wong, P. K., Entrepreneurial interest of university students in Singapore. Technovation, 24(2): 163-172. (2004).

[9] Baycan, T. and Nijkamp, P., Students' interest in an entrepreneurial career in a multicultural society. Research Memorandum, 34 (2011).

[10] Samuel, Y. A., Ernest, K. and Awuah, J. B., An assessment of entrepreneurship intention among Sunyani Polytechnic Marketing students. International Review of Management and Marketing, 3(1): 37 (2013).

[11] Ahmad, F. S., Baharun, R. and Rahman, S. H. A. Interest in entrepreneurship: An exploratory study on engineering and technical students in entrepreneurship education and choosing entrepreneurship as a career. Project Report, Faculty of Management and Human Resource Development, Skudai, Joho (2004).

[12] Gorman, G., Hanlon, D. and King, W., Some research perspectives on entrepreneurship education, enterprise education and education for small business management: a ten-year literature review. International Small Business Journal, 15(3): 56-77 (1997).

[13] Byers, T., Seelig, T., Sheppard, S. and Weilerstein, P. Summer Issue of the Bridge on Undergraduate Engineering Education. National Academy Of Engineering, Washington, DC, Vol. 43, No. 2. 


\title{
ريادة الأعمال وطلاب الهندسة السعوديين: الرغبة والكفاءات
}

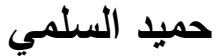 \\ قسم الهندسة الصناعبة، كلبة الهندسة، جامعة الملك عبد العزيز، جدة 1019 1 ، المدلكة العربية السعودية \\ healsulami@kau.edu.sa
}

المستخلص. في السنوات الأخيرة، فتحت ريادة الأعمال العديد من الأبواب والفرص للأفراد والمجتمعات على حد سواء. هنا في المملكة العربية السعودية، يمكن أن تقلل ريادة الأعمال

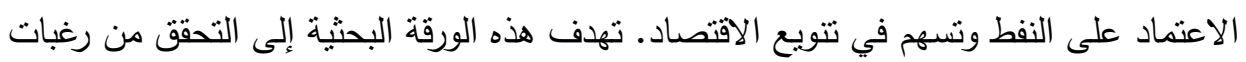

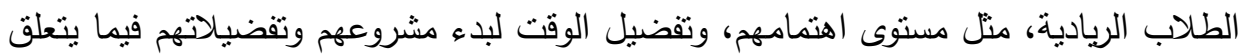
بالشراكة. وعلاوة على ذلك، فإنه يقيم مستوى تحصيل الطلاب من المهارات التي تعتبر ضرورية لنجاح رواد الأعمال. كما يقوم البحث بتقييم ما إذا كانت الجامعة لها أي دور في تزويد الطلاب بالمهارات اللازمة لبدء الأعمال. في هذه الدراسة نم استخدام الاستبانة لجمع البيانات لأسئلة البحث، وتم توزيعها على الطلاب في مناطق مختلفة من المملكة العربية السعودية. بينت نتائج الدراسة أن حوالي •^^ من طلاب الهندسة يهنمون بامتلاك شركاتهم الخاصة، والحافز الرئيسي

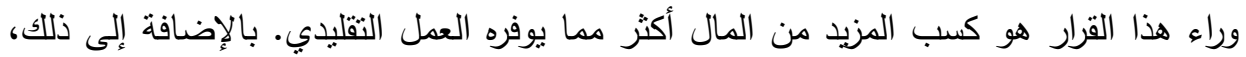
فإن غالبية الطلاب يفضلون العمل لبضع سنوات قبل المغامرة بالبدء في أعمالهم الخاصة. وتظهر النتائج أن المهارات والكفاءات، مثل: صنع القرار، والتواصل الفعال، والتفكير والتحليل الاستراتيجي، والمرونة والقيادة، قد نم الحصول عليها بمستوى أفضل من المهارات والكفاءات

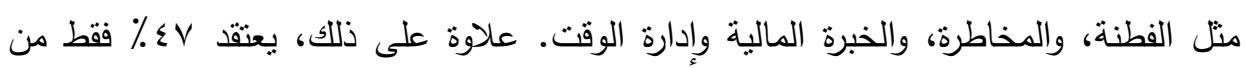

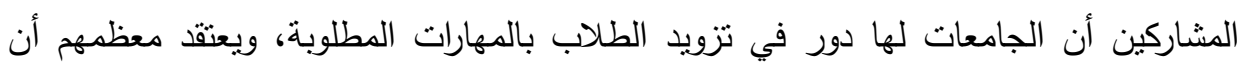
الجامعة قد ساعدتهم في الحصول على بعض المهارات، منل إدارة المشاريع، وذللك من خلال مواد الإدارة التي درسوها.

الكلمات الففتاحية: ريادة الأعمال، طلاب الهندسة، الرغبة، الكفاءات، المملكة العربية السعودية. 